\title{
Cytotoxic Substances Produced by a Fungal Strain from a Sponge: Physico-chemical Properties and Structures
}

\author{
Taro Amagata, Yoshihide Usami, Katsuhiko Minoura, \\ Tadayoshi Ito $^{\dagger}$ and Atsushi Numata* \\ Osaka University of Pharmaceutical Sciences, \\ 4-20-1 Nasahara, Takatsuki, Osaka 569-11, Japan \\ ${ }^{\dagger}$ Institute for Fermentation, Osaka, \\ Juso-Honmachi, Yodogawa-ku, Osaka 532, Japan
}

(Received for publication August 11, 1997)

Five novel metabolites, trichodenones $\mathrm{A} \sim \mathrm{C}(\mathbf{1} \sim \mathbf{3})$, harzialactone $\mathrm{A}(\mathbf{4})$ and $\mathrm{B}(\mathbf{5})$, have been isolated together with known $R$-mevalonolactone (6) from the culture broth of a strain of Trichoderma harzianum OUPS-N115 originally separated from the sponge Halichondria okadai. Their structures have been elucidated by spectral evidence. Among them, $1 \sim 3$ exhibited significant cytotoxicity against cultured P388 cells.

Marine microorganisms are potentially a prolific source of highly bioactive secondary metabolites that might represent useful leads in the development of new pharmaceutical agents. As part of a program designed to discover new antitumour metabolites produced by microorganisms inhabiting the marine environment, we previously reported that antitumour and cytotoxic compounds were produced by microorganisms originally isolated from the marine fishes Pseudolabrus japonicus ${ }^{1,2)}$ and Halichoeres bleekeri, ${ }^{3)}$ and the marine algae Enteromorpha intestinalis ${ }^{4 \sim 6)}$ and Sargassum tortile, ${ }^{7 \sim 10)}$ and their structures were established. In the present study, we examined secondary metabolites from a strain of Trichoderma harzianum OUPS-N115 originally separated from the sponge Halichondria okadai, and isolated six novel metabolites, designated trichodenones $\mathrm{A} \sim \mathrm{C}(\mathbf{1} \sim 3)$, harzialactone $\mathrm{A}(\mathbf{4})$ and $\mathrm{B}(5)$, along with known $R$-mevalonolactone (6) (Fig. 1). We describe herein the structure elucidation and cytotoxic activity of these metabolites.

\section{Results and Discussion}

A variety of microorganisms were initially isolated from the sponge Halichondria okadai, collected in the Tanabe Bay of Japan. Preliminary investigations in a

Fig. 1. Structures of trichodenones and harzialactones.

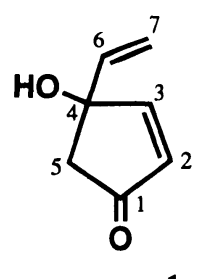

1<smiles>CC(O)C1(O)C=C(Cl)C(=O)C1</smiles>

2<smiles>CC(O)C1=C(Cl)C(=O)CC1</smiles>

3<smiles>[2H][C@H]1O[C@H](Cc2ccccc2)C[C@@H](O)[C@@H]1O</smiles>

4

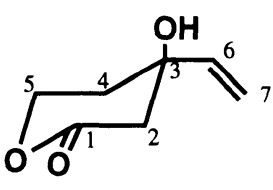<smiles>C[C@]1(O)CCOC(=O)C1</smiles> 
Table 1-1. Physico-chemical properties of trichodenones.

\begin{tabular}{|c|c|c|c|}
\hline & Trichodenone A (1) & Trichodenone B (2) & Trichodenone C (3) \\
\hline Appearance & Colorless oil & Colorless oil & Colorless oil \\
\hline $\mathrm{Mp}$ & - & - & - \\
\hline$[\alpha] \mathrm{D}$ & $+56.3^{\circ}\left(28^{\circ}, \mathrm{c} 0.75, \mathrm{CHCl}_{3}\right)$ & $-30.4^{\circ}\left(28^{\circ}, \mathrm{c} 0.34, \mathrm{CHCl}_{3}\right)$ & $-10.8^{\circ}\left(28^{\circ}\right.$, c $\left.1.11, \mathrm{CHCl}_{3}\right)$ \\
\hline Molecular formula & $\mathrm{C}_{7} \mathrm{H}_{8} \mathrm{O}_{2}$ & $\mathrm{C}_{7} \mathrm{H}_{9} \mathrm{O}_{3} \mathrm{Cl}$ & $\mathrm{C}_{7} \mathrm{H}_{9} \mathrm{O}_{2} \mathrm{Cl}$ \\
\hline \multirow[t]{2}{*}{ HREI-MS } & Calcd. for $\mathrm{C}_{7} \mathrm{H}_{8} \mathrm{O}_{2}: 125.0524$ & Calcd. for $\mathrm{C}_{7} \mathrm{H}_{10} \mathrm{O}_{3} \mathrm{Cl}: 177.0317$ & Calcd. for $\mathrm{C}_{7} \mathrm{H}_{9} \mathrm{O}_{2} \mathrm{Cl}: 160.0291$ \\
\hline & Obsd: $125.0524[\mathrm{M}]^{+}$ & Obsd: $177.0332[\mathrm{MH}]^{+}$ & Obsd: $160.0279[\mathrm{M}]^{+}$ \\
\hline $\mathrm{UV} \lambda_{\max }^{\text {Etoh }} \mathrm{nm}(\log \varepsilon)$ & $223(3.74)$ & $227(3.76)$ & $239(3.89)$ \\
\hline IR $\quad V_{\max }^{f_{1} i} \mathrm{~cm}^{-1}$ & $3419,1717,1683$ & $3419,1721,1683$ & $3419,1721,1683$ \\
\hline $\mathrm{CD} \lambda_{\max }^{\text {Etor }} \mathrm{nm}(\Delta \varepsilon)$ & $\begin{array}{l}220(0), 234(+0.44), 244 \\
(+0.09), 254(+0.11), 267 \\
(+0.03), 270(+0.05), 279(0) \\
\left(c \quad 4.80 \times 10^{-5} \mathrm{M} \text { in EtOH }\right)\end{array}$ & $\begin{array}{l}213(0), 233(+7.84), 270 \\
(0), 315(-1.99), 360(0) \\
\left(c \quad 2.28 \times 10^{-5} \mathrm{M} \text { in EtOH) }\right.\end{array}$ & $\begin{array}{l}267(0), 299(-0.68), 340(0) \\
\left(c \quad 2.88 \times 10^{-5} \mathrm{M} \text { in EtOH) }\right.\end{array}$ \\
\hline$R f$ value on TLC & $\begin{array}{l}0.366\left(\mathrm{CH}_{2} \mathrm{Cl}_{2}-\mathrm{MeOH}, 19: 1 \text {, }\right. \\
\text { silica gel) }\end{array}$ & $\begin{array}{l}0.207\left(\mathrm{CH}_{2} \mathrm{Cl}_{2}-\mathrm{MeOH}, 19: 1 \text {, }\right. \\
\text { silica gel) }\end{array}$ & $\begin{array}{l}0.450\left(\mathrm{CH}_{2} \mathrm{Cl}_{2}-\mathrm{MeOH}, 19: 1 \text {, }\right. \\
\text { silica gel) }\end{array}$ \\
\hline Solubility Soluble: & $\begin{array}{l}\mathrm{DMSO}, \mathrm{MeOH}, \mathrm{CHCl}_{3} \text {, } \\
\text { hexane, acetone, } \mathrm{AcOEt}\end{array}$ & $\begin{array}{l}\mathrm{DMSO}, \mathrm{MeOH}, \mathrm{CHCl}_{3} \text {, } \\
\text { hexane, acetone, } \mathrm{AcOEt}\end{array}$ & $\begin{array}{l}\text { DMSO, } \mathrm{MeOH}, \mathrm{CHCl}_{3} \text {, } \\
\text { hexane, acetone, AcOEt }\end{array}$ \\
\hline Insoluble: & $\mathrm{H}_{2} \mathrm{O}$ & $\mathrm{H}_{2} \mathrm{O}$ & $\mathrm{H}_{2} \mathrm{O}$ \\
\hline
\end{tabular}

a Measured in a tablet of $\mathrm{KBr}$.

Table 1-2. Physico-chemical properties of harzialactones.

\begin{tabular}{|c|c|c|}
\hline & Harzialactone A (4) & Harzialactone B (5) \\
\hline Appearance & Colorless powder & Colorless oil \\
\hline Mp & $82-84^{\circ} \mathrm{C}$ & - \\
\hline$[\alpha] \mathrm{D}$ & $+33.3^{\circ}\left(32^{\circ}, \mathrm{c} 0.3, \mathrm{CHCl}_{3}\right)$ & $-23.5^{\circ}\left(32^{\circ}\right.$, c $\left.1.76, \mathrm{CHCl}_{3}\right)$ \\
\hline Molecular formula & $\mathrm{C}_{11} \mathrm{H}_{12} \mathrm{O}_{3}$ & $\mathrm{C}_{7} \mathrm{H}_{10} \mathrm{O}_{3}$ \\
\hline \multirow[t]{2}{*}{ HREI-MS } & Calcd. for $\mathrm{C}_{11} \mathrm{H}_{12} \mathrm{O}_{3}: 192.0786$ & Calcd. for $\mathrm{C}_{7} \mathrm{H}_{10} \mathrm{O}_{3}: 142.0629$ \\
\hline & Obsd: $192.0786[\mathrm{M}]^{+}$ & Obsd: $142.0627[\mathrm{M}]^{+}$ \\
\hline $\mathrm{UV} \lambda_{\max }^{\mathrm{EtoH}} \mathrm{nm}(\log \varepsilon)$ & $285(2.61)$ & $223(2.66), 278(2.89)$ \\
\hline IR $v_{\max }^{\mathrm{fi} i} \mathrm{~cm}^{-1}$ & $3420,1771,1600,1580^{a}$ & $3420,1733,1684$ \\
\hline \multirow[t]{2}{*}{$\mathrm{CD} \lambda_{\max }^{\mathrm{EtoH}} \mathrm{nm}(\Delta \varepsilon)$} & $200(0), 220(-0.59), 255(0)$ & $201(0), 213(-0.69), 254(0)$ \\
\hline & (c $2.82 \times 10^{-4} \mathrm{M}$ in EtOH) & (c $3.96 \times 10^{-4} \mathrm{M}$ in EtOH) \\
\hline$R f$ value on TLC & $\begin{array}{l}0.438\left(\mathrm{CH}_{2} \mathrm{Cl}_{2}-\mathrm{MeOH}, 19: 1 \text {, }\right. \\
\text { silica gel) }\end{array}$ & $\begin{array}{l}0.125\left(\mathrm{CH}_{2} \mathrm{Cl}_{2}-\mathrm{MeOH}, 19: 1 \text {, }\right. \\
\text { silica gel })\end{array}$ \\
\hline Solubility Soluble: & $\begin{array}{l}\mathrm{DMSO}, \mathrm{MeOH}, \mathrm{CHCl}_{3} \text {, } \\
\text { hexane, acetone, AcOEt }\end{array}$ & $\begin{array}{l}\mathrm{DMSO}, \mathrm{MeOH}, \mathrm{CHCl}_{3} \text {, } \\
\text { hexane, acetone, AcOEt }\end{array}$ \\
\hline Insoluble: & $\mathrm{H}_{2} \mathrm{O}$ & $\mathrm{H}_{2} \mathrm{O}$ \\
\hline
\end{tabular}

$a$ Measured in a tablet of $\mathrm{KBr}$. 
small scale revealed that a mixture of crude metabolites in one of them, a strain of Trichoderma harzianum OUPS-N115, showed cytotoxic activity against the P388 lymphocytic leukemia test system in cell cuture. ${ }^{11)}$ In assays, the AcOEt extract of the culture filtrate showed $E_{50}$ value of $12 \mu \mathrm{g} / \mathrm{ml}$, whereas $E_{50}$ value of a methanolic extract of the mycelia was $>100 \mu \mathrm{g} / \mathrm{ml}$, suggesting that the activity was concentrated in the AcOEt soluble fraction of the culture filtrate. Consequently, full-scale experiments were carried out as follows.

The fungal strain was cultured at $27^{\circ} \mathrm{C}$ for 3 weeks in a medium containing $1 \%$ malt extract, $1 \%$ glucose and $0.05 \%$ peptone in artificial seawater. The AcOEt extract of the culture filtrate was purified by bioassay-directed fractionation employing a combination of Sephadex LH-20 and silica gel column chromatographies and HPLC to afford trichodenones $\mathrm{A} \sim \mathrm{C}(\mathbf{1} \sim \mathbf{3})$, harzialactone $\mathrm{A}(4)$ and $\mathrm{B}(5)$, and $R$-mevalonolactone (6). It was thought that the three trichodenones might be not obtained in reasonable yield due to their volatility; especially, trichodenone A which had highest volatility. The last known compound (6) was identified by comparison of spectral and other physical data with published values. ${ }^{12,13)}$

Trichodenone A (1) is a colorless oil with the properties listed in Table 1. The molecular formula of $\mathbf{1}$ was established as $\mathrm{C}_{7} \mathrm{H}_{8} \mathrm{O}_{2}$ by HR EI-MS $(m / z) 124.0524$ $\left.[\mathrm{M}]^{+}, \Delta 0.0 \mathrm{mmu}\right)$. Its UV and IR spectra exhibited absorption bands, characteristic of a conjugated enone (Table 1). A close inspection of the ${ }^{1} \mathrm{H}$ and ${ }^{13} \mathrm{C}$ NMR spectra of 1 (Table 2) by DEPT and ${ }^{1} \mathrm{H}^{1}{ }^{13} \mathrm{C}$ COSY experiments revealed the presence of a 1, 2-disubstituted double bond (C-2 and C-3), a vinyl group (C-6 and C-7), an $s p^{3}$-hybridized methylene (C-5), a 5-membered conjugated ketone (C-1) and a tertiary alcohol (C-4). Splitting patterns of the proton signals of the proton-bearing functional groups implied that no protons are present on carbons adjacent to these groups. Connection of these functional groups was clarified by long-range ${ }^{1} \mathrm{H}^{13} \mathrm{C}$ COSY correlations $(\mathrm{C}-1 / \mathrm{H}-5, \mathrm{C}-4 / \mathrm{H}-3, \mathrm{C}-4 / \mathrm{H}-6, \mathrm{C}-4 /$ $\mathrm{H}-7$, and $\mathrm{C}-6 / \mathrm{H}-5$ ) to lead to the planar structure 1 for trichodenone $\mathrm{A}$.

Trichodenone B (2) was isolated as a colorless oil with the molecular formula $\mathrm{C}_{7} \mathrm{H}_{9} \mathrm{O}_{3} \mathrm{Cl}$ determined by $[\mathrm{M}+$ $\mathrm{H}^{+}$data $(m / z 177.0332, \Delta 1.5 \mathrm{mmu})$ in HR EI-MS. The presence of one chlorine atom was supported by an intensity ratio of isotope peaks $\left([\mathrm{M}+\mathrm{H}]^{+} /[\mathrm{M}+\mathrm{H}+2]^{+}=\right.$ 3/1). The general features of its UV, IR, ${ }^{1} \mathrm{H}$ and ${ }^{13} \mathrm{C}$ NMR spectra (Table 1 and 2) closely resembled those of 1 except that the proton and carbon signals of the disubstituted olefin and the vinyl group in the NMR spectra of 1 were replaced by those of a trisubstituted olefin (C-2 and C-3) and a hydroxyethyl group (C-6 and C-7) $\left[\delta_{\mathrm{H}} 7.46(\mathrm{H}-3), \delta_{\mathrm{C}} 156.38(\mathrm{C}-3)\right.$ and $137.27(\mathrm{C}-2)$; $\delta_{\mathrm{H}} 1.23(\mathrm{H}-7)$ and $3.92(\mathrm{H}-6), \delta_{\mathrm{C}} 17.81(\mathrm{C}-7)$ and 76.60 (C-6)] in 2, respectively. Long-range ${ }^{1} \mathrm{H}^{13} \mathrm{C}$ COSY correlations $(\mathrm{C}-1 / \mathrm{H}-3, \mathrm{C}-4 / \mathrm{H}-5$ and $\mathrm{C}-4 / \mathrm{H}-7)$ in 2 implied

Table 2. ${ }^{1} \mathrm{H}$ and ${ }^{13} \mathrm{C}$ NMR data of $\mathbf{1} \sim \mathbf{3}$ in $\mathrm{CDCl}_{3}{ }^{\mathrm{a}}$.

\begin{tabular}{|c|c|c|c|c|c|c|c|c|c|c|c|c|}
\hline \multirow[b]{2}{*}{ No. } & \multicolumn{4}{|c|}{1} & \multicolumn{4}{|c|}{2} & \multicolumn{4}{|c|}{3} \\
\hline & $\delta_{\mathrm{H}}$ & $J \mathrm{~Hz}$ & $\delta_{\mathrm{c}}$ & $\begin{array}{r}\mathrm{LR}{ }^{1} \mathrm{H}^{-13} \mathrm{C} \\
\operatorname{CosY}(\mathrm{C})^{b} \\
\end{array}$ & $\delta_{\text {H }}$ & $J \mathrm{~Hz}$ & $\delta_{\mathrm{c}}$ & $\begin{array}{l}\text { LR }{ }^{\prime} \mathrm{H}^{-13} \mathrm{C} \\
\mathrm{COOSY}(\mathrm{C}) \\
\end{array}$ & $\delta_{\mathrm{H}}$ & $J \mathrm{~Hz}$ & $\delta_{\mathrm{c}}$ & $\begin{array}{l}\mathrm{LR}^{1}{ }^{1} \mathrm{H}^{-13} \mathrm{C} \\
\mathrm{COSY}(\mathrm{C}) \\
\end{array}$ \\
\hline 1 & & & 206.9 & 3,5 & & & 197.9 & 3 & & & 201.4 & \\
\hline 2 & $6.18 \mathrm{~d}$ & $5.5(3)^{\mathrm{c}}$ & 133.5 & & & & 137.3 & & & & 129.2 & \\
\hline 3 & $7.38 \mathrm{~d}$ & $5.5(2)$ & 164.7 & & $7.46 \mathrm{~s}$ & & 156.4 & & & & 175 & 7 \\
\hline 4 & & & 78.8 & $2,6,7$ & & & 78.9 & $5 \mathrm{~A}, 7$ & $2.54 \mathrm{t}$ & $4.5(5 \mathrm{~A})$ & 24.3 & \\
\hline $5 \mathrm{~A}$ & $2.60 \mathrm{~d}$ & $18.3(5 \mathrm{~B})$ & 49.6 & & $2.50 \mathrm{~d}$ & $18.9(5 \mathrm{~B})$ & 43.9 & & $2.71 \mathrm{dt}$ & $\begin{array}{l}19.2(5 \mathrm{~B}), \\
4.5(4)\end{array}$ & 32.7 & \\
\hline B & $2.63 \mathrm{~d}$ & $18.3(5 \mathrm{~A})$ & & & $2.76 \mathrm{~d}$ & $18.9(5 \mathrm{~A})$ & & & $2.76 \mathrm{~d}$ & $19.2(5 \mathrm{~A})$ & & \\
\hline 6 & $6.00 \mathrm{dd}$ & $\begin{array}{l}17.2(7 \mathrm{~B}), \\
10.6(7 \mathrm{~A})\end{array}$ & 140.3 & 5 & $3.92 \mathrm{q}$ & $6.5(7)$ & 76.6 & 7 & $5.08 \mathrm{q}$ & $6.7(7)$ & 65.4 & 7 \\
\hline $7 \mathrm{~A}$ & $5.24 \mathrm{~d}$ & $10.6(6)$ & 114.5 & & $1.23 \mathrm{~d}$ & $6.5(6)$ & 17.8 & & $1.44 \mathrm{~d}$ & $6.7(6)$ & 20.8 & \\
\hline B & $5.37 \mathrm{~d}$ & $17.2(6)$ & & & & & & & & & & \\
\hline $4-\mathrm{OH}$ & $2.87 \mathrm{br} \mathrm{s}$ & & & & $2.73 \mathrm{br}$ & & & & & & & \\
\hline $6-\mathrm{OH}$ & & & & & $2.09 \mathrm{brs}$ & & & & $2.43 \mathrm{br} \mathrm{s}$ & & & \\
\hline
\end{tabular}

${ }^{a}$ Measured at 300 and $75.4 \mathrm{MHz}$ for ${ }^{1} \mathrm{H}$ and ${ }^{13} \mathrm{C}$, respectively. ${ }^{b} \mathrm{LR}{ }^{1} \mathrm{H}-{ }^{13} \mathrm{C}$ COSY correlations from $\mathrm{C}$ to $\mathrm{H}$.

${ }^{\mathrm{c}}$ Figures in parentheses indicate a proton coupling with that question. 
that the hydroxyethyl group is located at C-4 and the olefin links to $\mathrm{C}-1$ and $\mathrm{C}-4$. The carbon signal of the conjugated ketone (C-1) was found shifted upfield by $c a$. $10 \mathrm{ppm}$, relative to a general conjugated cyclopentenone $\left(\delta_{\mathrm{C}} 209\right)^{14)}$ and 1 . It has been observed that carbon signals of $\alpha$-haloketones such as 2-chlorocyclopentanone, 2chlorocyclohexanone, 2-chloro- $p$-benzoquinone, ${ }^{15)}$ gymnastatin $\mathrm{A}^{16)}$ etc. appear shifted upfield by $8 \sim 10 \mathrm{ppm}$, relative to the corresponding ketone ${ }^{15,17)}$ bearing no halogen atom. These observations suggested that a chlorine atom exists at the $\alpha$-position of the ketone in $\mathbf{2}$, and hence structure $\mathbf{2}$ was established for trichodenone B.

Trichodenone $\mathrm{C}(3)$ was assigned a molecular formula of $\mathrm{C}_{7} \mathrm{H}_{9} \mathrm{O}_{2} \mathrm{Cl}$ as deduced from $[\mathrm{M}]^{+}$peak in HREI-MS and the intensity ratio of isotope peaks $\left([\mathrm{M}]^{+} /[\mathrm{M}+\right.$ $2]^{+}=3 / 1$ ). The general spectral features of its UV, IR, ${ }^{1} \mathrm{H}$ and ${ }^{13} \mathrm{C}$ NMR spectra showed close correspondence with those of 2, except that the carbon signal of the tertiary alcohol and the proton signal of the trisubstituted olefin in the NMR spectra of $\mathbf{2}$ were missing and replaced by those of a methylene group (C-4) and a tetrasubstituted olefin (C-2 and C-3) in 3, respectively (Table 1 and 2). The methylene protons showed a correlation with the $\mathrm{C}-5$ methylene protons in ${ }^{1} \mathrm{H}-{ }^{1} \mathrm{H}$ COSY, and one $s p^{2}$-carbon (C-3) of the olefin was correlated with the methyl protons (H-7) of the hyroxyethyl group in longrange ${ }^{1} \mathrm{H}^{13} \mathrm{C}$ COSY. This evidence led to structure 3 for trichodenone $\mathrm{C}$.

The absolute stereochemistry of the three trichodenones described above could not be established from the spectroscopic data, and hence was determined by their stereospecific total syntheses, which will be reported elsewhere.

Harzialactone A (4) had the molecular formula $\mathrm{C}_{11} \mathrm{H}_{12} \mathrm{O}_{3}$ established by HREI-MS. Its IR spectrum contained absorption bands, characteristic of a hydroxyl group, a $\gamma$-lactone and an aromatic ring (Table 1). A close inspection of the ${ }^{1} \mathrm{H}$ and ${ }^{13} \mathrm{C}$ NMR spectral data (Table 2) of 4 by DEPT and ${ }^{1} \mathrm{H}^{-1}{ }^{13} \mathrm{C}$ COSY experiments revealed the presence of one $\gamma$-lactone (C-1), one phenyl group (C-6 C -11), two $s p^{3}$-hybridized methylenes (C-3 and $\mathrm{C}-5$ ) including one benzylic methylene, and two $s p^{3}$-methines (C-2 and C-4) linking to the hydroxyl and carbonyloxy groups, respectively. Analysis of coupling relationships of the proton signals, ${ }^{1} \mathrm{H}^{-1} \mathrm{H}$ COSY and HMBC (C-2/H-3, C-3/H-5, C- $4 / \mathrm{H}-5$ and C-7/H-5) correlations led to planar structure of 4 .

The relative stereochemistry for $\mathbf{4}$ was established by comparison of the observed coupling constants (Table 3) and NOE data with those of two related compounds, antafumicins A (7) and B (8) (Fig. 2), which have been

Table 3. ${ }^{1} \mathrm{H}$ and ${ }^{13} \mathrm{C} \mathrm{NMR}$ data of 4 and 5 in $\mathrm{CDCl}_{3}{ }^{\mathrm{a}}$.

\begin{tabular}{|c|c|c|c|c|c|c|c|}
\hline \multirow[b]{2}{*}{ No. } & \multicolumn{4}{|c|}{4} & \multicolumn{3}{|c|}{5} \\
\hline & $\delta_{\text {н }}$ & $J \mathrm{~Hz}$ & $\delta_{\mathrm{c}}$ & $\begin{array}{l}\mathrm{LR}{ }^{1} \mathrm{H}-{ }^{13} \mathrm{C} \\
\operatorname{CosY}(\mathrm{C})^{b}\end{array}$ & $\delta_{\mathrm{H}}$ & $J \mathrm{~Hz}$ & $\delta_{\mathrm{c}}$ \\
\hline 1 & & & 177.1 & & & & 169.6 \\
\hline $2 \alpha$ & $3.99 \mathrm{td}$ & $8.3(3 \alpha \cdot 3 \beta) \cdot 1.9(\mathrm{OH})^{\mathrm{c}}$ & 67.0 & $3 \beta$ & $2.68 \mathrm{~d}$ & $16.6(2 \beta)$ & 42.4 \\
\hline$\beta$ & & & & & $2.66 \mathrm{~d}$ & $16.6(2 \alpha)$ & \\
\hline $3 \alpha$ & $2.38 \mathrm{ddd}$ & $13.2(3 \beta), 8.3(2), 3.5(4)$ & 34.3 & 5 & & & 70.4 \\
\hline$\beta$ & $2.29 \mathrm{dt}$ & $13.2(3 \alpha), 8.3(2,4)$ & & & & & \\
\hline $4 \alpha$ & & & 78.1 & 5 & $2.09 \mathrm{ddd}$ & $14.2(4 \beta), 10.3(5 \beta), 5.4(5 \alpha)$ & 34.3 \\
\hline$\beta$ & $4.92 \mathrm{dtd}$ & $8.3(3 \beta), 5.5(5 \mathrm{~A}, \mathrm{~B}), 3.5(3 \alpha)$ & & & $1.93 \mathrm{dt}$ & $14.2(4 \alpha), 4.1(5 \alpha, 5 \beta)$ & \\
\hline $5 \alpha(\mathrm{A})$ & $2.98 \mathrm{dd}$ & $15(5 \mathrm{~B}), 5.5(4)$ & 41.1 & & 4.36 ddd & $11.3(5 \beta), 5.4(4 \alpha), 4.1(4 \beta)$ & 65.7 \\
\hline$\beta(\mathrm{B})$ & $3.00 \mathrm{dd}$ & $15(5 \mathrm{~A}), 5.5(4)$ & & & $4.65 \mathrm{ddd}$ & $11.3(5 \alpha), 10.3(4 \alpha), 4.1(4 \beta)$ & \\
\hline 6 & & & 135.2 & 5 & $5.98 \mathrm{dd}$ & $17.3(7), 10.7(7)$ & 141.9 \\
\hline \multirow[t]{2}{*}{7} & $7.22 \mathrm{~d}$ & $8.1(8), 1.7(9)$ & 129.6 & 5 & $5.24 \mathrm{~d}$ & $10.7(6)$ & 114.4 \\
\hline & & & & & $5.35 \mathrm{~d}$ & $17.3(6)$ & \\
\hline 8 & $7.34 \mathrm{~m}$ & & 128.9 & 10 & & & \\
\hline 9 & $7.31 \mathrm{~m}$ & & 127.3 & 7,11 & & & \\
\hline 10 & $7.34 \mathrm{~m}$ & & 128.9 & 8 & & & \\
\hline 11 & $7.22 \mathrm{~d}$ & $8.1(10), 1.7(9)$ & 129.6 & 5 & & & \\
\hline $\mathrm{OH}$ & $2.46 \mathrm{br} \mathrm{d}$ & $1.9(2)$ & & & 1.88 br s & & \\
\hline
\end{tabular}

${ }^{a}$ Measured at 300 and $75.4 \mathrm{MHz}$ for ${ }^{1} \mathrm{H}$ and ${ }^{13} \mathrm{C}$, respectively.

${ }^{b}$ Long range ${ }^{1} \mathrm{H}-{ }^{13} \mathrm{C}$ COSY correlations

from $\mathrm{C}$ to $\mathrm{H}$. $\quad{ }^{\mathrm{c}}$ Figures in parentheses indicate a proton coupling with that question. 
Fig. 2. Structures of antafumicins.

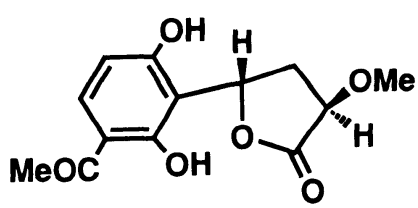

7

Fig. 3. ${ }^{1} \mathrm{H}$ chemical shift differences $(\Delta \delta=$ $\left.\delta_{\mathrm{S}}-\delta_{\mathrm{R}}\right)$ between the $(R)$ - and $(S)$-MTPA esters (9a and 9b).

$\Delta \delta$ values are expressed in hertz $(500 \mathrm{~Hz})$.

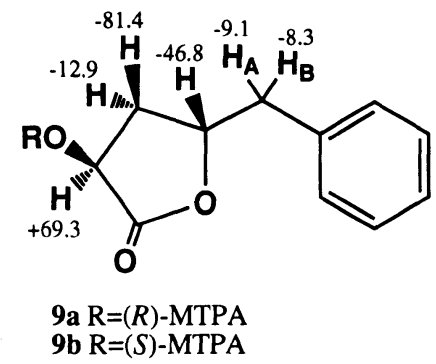

isolated from the fermentation broth of Aspergillus niger NH-401 by Fujimoto et al. ${ }^{18,19)}$. The coupling relationship of H-2 and H-4 to H-3 $\left(J_{2,3 \alpha}=J_{2,3 \beta}=J_{3 \beta, 4}=8.3 \mathrm{~Hz}\right.$ and $J_{3 \beta, 4}=3.5 \mathrm{~Hz}$ ) in 4 was closely similar to that of antafumicin A (7) $\left[\left(J_{2,3 \mathrm{~A}}=10.7 \mathrm{~Hz}, J_{2,3 \mathrm{~B}}=9.1 \mathrm{~Hz}\right.\right.$, $J_{3 \mathrm{~A}, 4}=9.4 \mathrm{~Hz}$ and $\left.\left.J_{3 \mathrm{~B}, 4}=5.2 \mathrm{~Hz}\right)\right]$ rather than that of antafumicin B (8) $\left[\left(J_{2,3 \mathrm{~A}}=8.8 \mathrm{~Hz}, J_{2,3 \mathrm{~B}}=4.9 \mathrm{~Hz}, J_{3 \mathrm{~A}, 4}=\right.\right.$ $8.6 \mathrm{~Hz}$ and $\left.\left.J_{3 \mathrm{~B}, 4}=10.4 \mathrm{~Hz}\right)\right]$. Furtheremore, in NOESY experiments of 4, NOEs between $\mathrm{H}-2$ and $\mathrm{H}-3 \alpha$, and between $\mathrm{H}-4$ and $\mathrm{H}-3 \beta$ were observed, whereas an NOE was not observed between $\mathrm{H}-2$ and $\mathrm{H}-4$. An NOE between $\mathrm{H}-2$ and $\mathrm{H}-4$ has been observed in antafumicin B (8), but not in 7. Similarity of the coupling and NOE relationship between 4 and 7 as described above suggested that 4 contains trans- $\gamma$-lactone. The absolute configuration of this compound (4) was established by application of the modified MosHeR's method. ${ }^{20)}$ The ${ }^{1} \mathrm{H}$ chemical shift differences between the $(R)$ - and $(S)$ 2-methoxy-2-phenyl-2-(trifluoromethyl)acetic acid (MTPA) esters (9a and 9b) were observed as shown in Fig. 3. This result suggested the $2 S$ and $4 S$ configurations and consequently led to the absolute stereostructure 4 for harzialactone A.

Harzialactone B (5) had the molecular formula $\mathrm{C}_{7} \mathrm{H}_{10} \mathrm{O}_{3}$ established by HREI-MS. Its IR spectrum

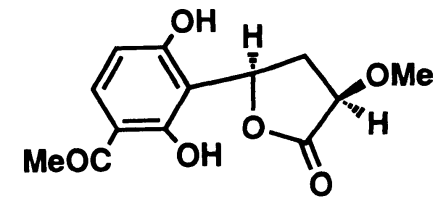

8

contained absorption bands, characteristic of a hydroxyl group, a $\delta$-lactone and a double bond. Analysis of the ${ }^{1} \mathrm{H}$ and ${ }^{13} \mathrm{C}$ NMR spectral data (Table 3 ) of 5 by DEPT and ${ }^{1} \mathrm{H}-{ }^{13} \mathrm{C} C O S Y$ experiments revealed the presence of one $\delta$-lactone $(\mathrm{C}-1)$, vinyl group (C-6 C-7), tertiary alcohol $(\mathrm{C}-3)$ each and three $s p^{3}$-hybridized methylenes (C-2, C-4 and C-5) including one oxygen-bearing methylene. Chemical shifts, coupling relationships and ${ }^{1} \mathrm{H}-{ }^{1} \mathrm{H}$ COSY correlations for the three $s p^{3}$-methylene protons led to planar structure of $\mathbf{5}$. The coupling constants between $\mathrm{H}-4$ and $\mathrm{H}-5\left(J_{4 \mathrm{~B}, 5 \mathrm{~B}}=10.3 \mathrm{~Hz}, J_{4 \mathrm{~B}, 5 \mathrm{~A}}=\right.$ $5.4 \mathrm{~Hz}$ and $J_{4 \mathrm{~A}, 5 \mathrm{~A}}=J_{4 \mathrm{~A}, 5 \mathrm{~B}} 4.1 \mathrm{~Hz}$ ) suggested 5 to exist in a chair conformation in $\mathrm{CDCl}_{3}$ solution. In the circular dichroism (CD) spectrum of $\mathbf{5}$, there was a negative band at $213 \mathrm{~nm}$ (Table 1) due to an $\mathrm{n} \rightarrow \pi^{*}$ transition in a carbonyl chromophore, comparable in wave length and strength to that of the related compound 6 (see Experimental), showing 5 to have the same configuration $(3 R)$ as that of 6.

Cytotoxic activities of compounds $(\mathbf{1} \sim \mathbf{6})$ described above were examined in the P388 lymphocytic leukemia test system in cell cuture. ${ }^{11)}$ The results are listed in Table 4 , and imply that $1 \sim 3$ exhibited significant cytotoxicity.

\section{Experimental}

General

UV spectra were recorded on a Shimadzu spectrophotometer and IR spectra on a Perkin Elmer FT-IR spectrometer 1720X. Optical rotations were obtained on a JASCO ORD/UV-5 spectropolarimeter. NMR spectra were recorded at $27^{\circ} \mathrm{C}$ on a Varian XL-300 spectrometer, operating at 300 and $75.4 \mathrm{MHz}$ for ${ }^{1} \mathrm{H}$ and ${ }^{13} \mathrm{C}$, respectively, in $\mathrm{CDCl}_{3}$ with TMS as an internal reference. EI-MS was determined using a Hitachi $\mathrm{M}-4000 \mathrm{H}$ mass spectrometer. Liquid chromatography was performed over Sephadex LH-20 and silica gel 60 (mesh 230 400, Nacalai Tesque) in an ordinary and a medium pressure, respectively. HPLC was run on a Waters ALC-200 instrument equipped with a differential refractometer $(\mathrm{R}$ 
Table 4. Cytotoxicity of compounds $1 \sim 6$ against P388 cell line ${ }^{\mathrm{a}}$.

\begin{tabular}{lc}
\hline \hline Compound & $\mathrm{ED}_{50}(\mu \mathrm{g} / \mathrm{ml})$ \\
\hline Trichodenone A (1) & 0.21 \\
Trichodenone B (2) & 1.21 \\
Trichodenone C (3) & 1.45 \\
Harzialactone A (4) & $>100$ \\
Harzialactone B (5) & 60 \\
R-Mevalonolactone (6) & $>100$ \\
Mitomycin C & 0.05 \\
5-FU & 0.07 \\
\hline${ }^{b}$ DMSO was used as vehicle in the tests of all compounds. For significant \\
activity, an $\mathrm{ED}_{50}$ value $\leq 4 \mu \mathrm{g} / \mathrm{ml}^{21}$ is required. ${ }^{21}$ Used as standard.
\end{tabular}

401) and Shim-pack PREP-ODS (25 $\mathrm{cm} \times 20 \mathrm{~mm}$ i.d.). Analytical TLC was performed on precoated Merck aluminium sheets (DC-Alufolien Kieselgel $60 \mathrm{~F}_{254}$, $0.2 \mathrm{~mm}$ ) and precoated plates RP-18 $\mathrm{F}_{254 \mathrm{~s}}$, and compounds were viewed under UV lamp and sprayed with $10 \% \mathrm{H}_{2} \mathrm{SO}_{4}$ followed by heating.

\section{Fermentation}

The sponge Halichondria okadai, collected in the Tanabe Bay of Japan, was homogenized with sterile artificial seawater and applied to the surface of nutrient agar layered in a Petri dish. Serial transfers of one of the resulting colonies provided a pure strain of Trichoderma harzianum Rifai OUPS-N115. The fungal strain was grown in a liquid medium (300 liters) containing $1 \%$ glucose, $0.05 \%$ peptone and $1 \%$ malt extract in artificial seawater adjusted to $\mathrm{pH} 7.5$ for three weeks at $27^{\circ} \mathrm{C}$.

\section{Isolation of Metabolites}

The culture filtrate was extracted thrice with AcOEt. The combined extracts were evaporated in vacuo to give a mixture of crude metabolites $(17.7 \mathrm{~g})$. The mixture was passed through Sephadex LH-20, using $\mathrm{CH}_{2} \mathrm{Cl}_{2}-\mathrm{MeOH}$ $(1: 1)$ as the eluent. The second fraction $(\mathrm{A}, 10.2 \mathrm{~g})$, in which cytotoxic activity was concentrated, was chromatographed on a silica gel column with a $\mathrm{CH}_{2} \mathrm{Cl}_{2}-\mathrm{MeOH}$ gradient $(100: 0 \rightarrow 0: 100)$ as the eluent. Fractions $\mathrm{B}$ (237 mg) and $\mathrm{C}(216.1 \mathrm{mg})$, eluted with $\mathrm{CH}_{2} \mathrm{Cl}_{2}$ and $\mathrm{MeOH}-\mathrm{CH}_{2} \mathrm{Cl}_{2}$ (1:99), respectively, and two fractions D (534.5 mg) and E (137.9 mg), eluted with $\mathrm{MeOH}$ $\mathrm{CH}_{2} \mathrm{Cl}_{2}$ (1:49), were used to next purification. The fraction $\mathrm{B}$ was further chromatographed on silica gel with a $\mathrm{CH}_{2} \mathrm{Cl}_{2}-\mathrm{MeOH}$ gradient $(100: 0 \rightarrow 0: 100)$ as the eluent. The $\mathrm{MeOH}-\mathrm{CH}_{2} \mathrm{Cl}_{2}(2: 98)$ eluate $(\mathrm{F}, 131.1 \mathrm{mg})$ was separated by HPLC using $\mathrm{MeOH}-\mathrm{H}_{2} \mathrm{O}(1: 4)$ as the eluent to afford two fractions $G(47.1 \mathrm{mg})$ and $\mathrm{H}$ (17.4 mg). The fraction $\mathrm{H}$ afforded 4 (7.3 $\mathrm{mg}$ ) after purification by repeated HPLC. The fraction $G$ was purified by $\mathrm{HPLC}$ using $\mathrm{MeOH}-\mathrm{H}_{2} \mathrm{O}(2: 3)$ as the eluent to afford $1(18.6 \mathrm{mg})$ and $3(7.8 \mathrm{mg})$. The $\mathrm{MeOH}-\mathrm{CH}_{2} \mathrm{Cl}_{2}$ $(1: 49)$ eluate (I, $145.8 \mathrm{mg}$ ) from silica gel column chromatography of the fraction $\mathrm{C}$ was repeatedly purified by HPLC using $\mathrm{MeOH}-\mathrm{H}_{2} \mathrm{O}(1: 4,2: 3$ and $3: 2)$ as the eluent to afford $5(8.4 \mathrm{mg})$. The $\mathrm{MeOH}-\mathrm{CH}_{2} \mathrm{Cl}_{2}$ (1: 199) eluate $(\mathrm{J}, 413.7 \mathrm{mg})$ from silica gel column chromatography of the fraction D afforded $6(23.2 \mathrm{mg})$ after purification by $\mathrm{HPLC}$ using $\mathrm{MeOH}-\mathrm{H}_{2} \mathrm{O}(1: 4)$ as the eluent. The $\mathrm{MeOH}-\mathrm{CH}_{2} \mathrm{Cl}_{2}(1: 99)$ eluate $(\mathrm{K}, 52.3 \mathrm{mg})$ from silica gel column chromatography of the fraction E was repeatedly purified by $\mathrm{HPLC}$ using $\mathrm{MeOH}-\mathrm{H}_{2} \mathrm{O}$ $(3: 7,2: 3$ and $1: 1)$ as the eluent to afford $2(6.0 \mathrm{mg})$.

$R$-Mevalonolactone (6)

Colorless oil, $[\alpha]_{\mathrm{D}}-25.6^{\circ}\left(25^{\circ}, c 0.2, \mathrm{EtOH}\right)$; EI-MS $m / z: 130[\mathrm{M}]^{+}$. UV $\lambda_{\max }^{\mathrm{EtOH}} \mathrm{nm}(\log \varepsilon): 226(3.27), 279$ (3.93). IR $v_{\max }^{\mathrm{film}} \mathrm{cm}^{-1}: 3419,1738$. CD $\lambda_{\max }^{\mathrm{EtOH}} \mathrm{nm}(\Delta \varepsilon)(c$ $4.05 \times 10^{-4} \mathrm{M}$ in EtOH): $219(-0.56) .{ }^{1} \mathrm{H}$ NMR $\delta \mathrm{ppm}$ $\left(\mathrm{CDCl}_{3}\right): 1.40(3 \mathrm{H}, \mathrm{s}, \mathrm{H}-6), 1.91(1 \mathrm{H}, \mathrm{m}, \mathrm{H}-4 \beta), 1.96$ $(1 \mathrm{H}, \mathrm{m}, \mathrm{H}-4 \alpha), 2.41(1 \mathrm{H}, \mathrm{d}, J=17.3 \mathrm{~Hz}, \mathrm{H}-2 \alpha), 2.67(1 \mathrm{H}$, dd, $J=17.3,2.2 \mathrm{~Hz}, \mathrm{H}-2 \beta), 2.78(1 \mathrm{H}$, br s, OH), $4.36(1 \mathrm{H}$, ddd, $J=11.3,5.0,4.0 \mathrm{~Hz}, \mathrm{H}-5 \alpha), 4.61(1 \mathrm{H}$, ddd, $J=11.3$, $8.7,6.4 \mathrm{~Hz}, \mathrm{H}-5 \beta) ;{ }^{13} \mathrm{C} \mathrm{NMR} \delta \mathrm{ppm}\left(\mathrm{CDCl}_{3}\right): 29.8(\mathrm{C}-6)$, 35.9 (C-4), 44.7 (C-2), 66.0 (C-5), 68.3 (C-3), 170.5 (C-1). These ${ }^{1} \mathrm{H}$ and ${ }^{13} \mathrm{C}$ NMR data and specific rotation were identical with published values, ${ }^{12,13}$ ) though detailed coupling relationships of proton signals were not shown in the previous paper. 
Formation of the $(R)$ - and $(S)$-MTPA esters 9a and $9 \mathrm{~b}$ from harzialactone $\mathrm{A}(4)$

$(R)$-MTPA ( $5 \mathrm{mg})$, DCC ( $5 \mathrm{mg})$ and DMAP (3 mg) was added to a $\mathrm{CH}_{2} \mathrm{Cl}_{2}$ solution $(1 \mathrm{ml})$ of harzialactone $\mathrm{A}$ (4) $(0.7 \mathrm{mg})$, and the reaction mixture was left at room temperature for 2 hours. The solvent was evaporated off under reduced pressure, and the residue was purified by HPLC (ODS) using $80 \% \mathrm{MeOH}$ in $\mathrm{H}_{2} \mathrm{O}$ to afford 9a $(0.8 \mathrm{mg})$. The same reaction with $4(0.7 \mathrm{mg})$ using $(S)$-MTPA $(5 \mathrm{mg})$ gave $9 \mathbf{b}(0.9 \mathrm{mg})$.

9a: Obtained as colorless oil; $m / z$ (EI) $390\left(\mathrm{M}^{+}\right) .{ }^{1} \mathrm{H}$ NMR $\delta_{\mathrm{H}}\left(500 \mathrm{MHz} ; \mathrm{CDCl}_{3}\right): 2.43(1 \mathrm{H}, \mathrm{dt}, J=13.7$ and 8.0, 3 $\beta-\mathrm{H}), 2.49(1 \mathrm{H}$, ddd, $J=13.7,9.0$ and $3.9,3 \alpha-\mathrm{H})$, $3.01\left(1 \mathrm{H}, \mathrm{dd}, J=14.2\right.$ and $\left.5.5,5-\mathrm{H}_{\mathrm{A}}\right), 3.05(1 \mathrm{H}$, dd, $J=14.2$ and $\left.5.5,5-\mathrm{H}_{\mathrm{B}}\right), 3.49(3 \mathrm{H}, \mathrm{s}, \mathrm{OMe}), 5.00(1 \mathrm{H}, \mathrm{dtd}$, $J=8.0,5.5$ and $3.9,4 \beta-\mathrm{H}), 5.02(1 \mathrm{H}, \mathrm{dd}, J=9.0$ and 8.0 , $2 \alpha-\mathrm{H}), 7.23(2 \mathrm{H}, \mathrm{m}, \mathrm{Ar}-\mathrm{H}), 7.35(6 \mathrm{H}, \mathrm{m}, \mathrm{Ar}-\mathrm{H}), 7.52$ $(2 \mathrm{H}, \mathrm{m}, \mathrm{Ar}-\mathrm{H})$.

9b: Obtained as colorless oil; $m / z$ (EI) $390\left(\mathrm{M}^{+}\right) .{ }^{1} \mathrm{H}$ NMR $\delta_{\mathrm{H}}\left(500 \mathrm{MHz} ; \mathrm{CDCl}_{3}\right): 2.26(1 \mathrm{H}, \mathrm{dt}, J=13.8$ and $7.9,3 \beta-\mathrm{H}), 2.46(1 \mathrm{H}$, ddd, $J=13.8,9.0$ and $3.7,3 \alpha-\mathrm{H})$, $3.00\left(1 \mathrm{H}, \mathrm{dd}, J=14.2\right.$ and $\left.5.6,5-\mathrm{H}_{\mathrm{A}}\right), 3.03(1 \mathrm{H}, \mathrm{dd}$, $J=14.2$ and $\left.5.6,5-\mathrm{H}_{\mathrm{B}}\right), 3.57(3 \mathrm{H}, \mathrm{s}, \mathrm{OMe}), 4.91(1 \mathrm{H}, \mathrm{dtd}$, $J=7.9,5.6$ and $3.7,4 \beta-\mathrm{H}), 5.15(1 \mathrm{H}, \mathrm{dd}, J=9.0$ and 7.9 , $2 \alpha-\mathrm{H}), 7.22(2 \mathrm{H}, \mathrm{m}, \mathrm{Ar}-\mathrm{H}), 7.36(6 \mathrm{H}, \mathrm{m}, \mathrm{Ar}-\mathrm{H}), 7.50$ $(2 \mathrm{H}, \mathrm{m}, \mathrm{Ar}-\mathrm{H})$.

\section{Acknowledgments}

We are grateful to Ms. H. Fujitake, this university, for the MS measurements.

\section{References}

1) Numata, A.; C. Takahashi, T. Matsushita, T. Miyamoto, K. Kawai, Y. Usami, M. Inoue, H. Ohishi \& T. SHINGU: Fumiquinazolines, novel metabolites of a fungus isolated from a saltfish. Tetrahedron Lett. 33: $1621 \sim 1624,1992$

2) Takahashi, C.; T. Matsushita, M. Doi, K. Minoura, T. Shingu, Y. Kumeda \& A. Numata: Fumiquinazolines $A \sim G$, novel metabolites of a fungus separated from a Pseudolabrus marine fish. J. Chem. Soc., Perkin Trans. 1: $2345 \sim 2353,1995$

3) Takahashi, C.; T. Takada, T. Yamada, K. Minoura, K. UChIDA, E. MatSUmURA \& A. Numata: Halichomycin, a new class of potent cytotoxic macrolide produced by an actinomycete from a marine fish. Tetrahedron Lett. 35: $5013 \sim 5014,1994$

4) Numata, A.; C. Takahashi, Y. Ito, T. Takada, K. Kawai, Y. Usami, E. Matsumura, M. Imachi, T. Ito \& T. Hasegawa: Communesins, cytotoxic metabolites of a fungus isolated from a marine alga. Tetrahedron Lett. 34: 2355 2358, 1993

5) Numata, A.; C. Takahashi, Y. Ito, K. Minoura, T. Yamada, C. Matsuda \& K. Nomoto: Penochalasins, a novel class of cytotoxic cytochalasans from a Penicillium species separated from a marine alga: Structure determination and solution conformation. J. Chem. Soc., Perkin Trans 1: 239 245, 1996

6) Takahashi, C.; A. Numata, T. Yamada, K. Minoura, S. Enomoto, K. Konishi, M. NaKai, C. Matsuda \& K. Nomoto: Penostatins, novel cytotoxic metabolites from a Penicillium species separated from a green alga. Tetrahedron Lett. 37: 655 658, 1996

7) Takahashi, C.; A. Numata, Y. Ito, E. Matsumura, H. Araki, H. IwaKi \& K. Kushida: Leptosins, antitumour metabolites of a fungus isolated from a marine alga. $\mathbf{J}$. Chem. Soc., Perkin Trans. 1: 1859 1864, 1994

8) Takahashi, C.; A. Numata, E. Matsumura, K. Minoura, H. Eto, T. Shingu, T. Ito \& T. Hasegawa: Leptosins I and $\mathrm{J}$, cytotoxic substances produced by a Leptoshaeria sp. J. Antibiot. 47: 1242 1249, 1994

9) Takahashi, C.; K. Minoura, T. Yamada, A. Numata, K. Kushida, T. Shingu, S. Hagishita, H. Nakai, T. Sato \& H. Harada: Potent cytotoxic metabolites from a Leptosphaeria species. Structure determination and conformational analysis. Tetrahedron 51: 3483 3498, 1995

10) Takahashi, C.; Y. Takai, Y. Kimura, A. Numata, N. Shigematsu \& H. Tanaka: Cytotoxic metabolites from a fungal adherent of a marine alga. Phytochemistry 38 : $155 \sim 158,1995$

11) Numata, A.; P. Yang, C. Takahashi, R. Fujiki, M. NABAE \& E. Fujita: Cytotoxic triterpenes from a Chinese medicine, goreishi. Chem. Pharm. Bull. 37: 648 651, 1989

12) Mori, K. \& K. Okada: Synthesis of mevalonolactone (hiochic acid lactone) employing asymmetric epoxidation as the key-step. Tetrahedron 41: 557 559, 1985

13) Mash, E. A. \& J. B. Arterburn: Enatiomerically pure acetals in organic synthesis. 3. A synthesis of $(R)$ mevalonic acid lactone. J. Org. Chem. 56: 885 888, 1991

14) Pretsch, E.; T. Clerc, J. Seibl \& W. Simon: In Tabellen zur Strukturaufklarung organischer Verbindungen mit spectroskopischen Methoden. Japanese version (Transl. K. NaKanishi et al.), p. 146, KS, Tokyo, 1982

15) Pouchert, C. J. \& J. Behnke: The Aldrich Library of ${ }^{13} \mathrm{C}$ and ${ }^{1} \mathrm{H}$ FTNMR Spectra, Edition 1, Vol. 1, pp. 666 669, 673, 713, 715, Aldrich Chemical Company, 1993

16) Numata, A.; T. Amagata, K. Minoura \& T. Ito: Gymnastatins, novel cytotoxic metabolites produced by a fungal strain from a sponge. Tetrahedron Lett. 32: $5675 \sim 5678,1997$

17) Higa, T.: 2-(1-Chloro-2-hydroxyethyl)-4,4-dimethylcyclohexa-2,5-dione: A precursor of 4,5-dimethylbenzo[b]furan from the red alga Desmia hornemanni. Tetrahedron Lett. 26: $2335 \sim 2336,1985$

18) Fujimoto, Y.; K. Okamura, T. Ukita, H. Miyagawa, K. Nishimura, T. Ueno, T. Tsurushima \& H. Irie : Structure and synthesis of antafumicins $\mathrm{A}$ and $\mathrm{B}$, novel antifungal substances produced by Aspergillus niger NH-401. 35th Symposium on the Chemistry of Natural Products, Symposium Papers, pp. 662 669, 1993

19) Fujimoto, Y.; H. Miyagawa, T. Tsurushima, H. Irie, K. Okamura \& T. Ueno: Structures of antafumicins A and $B$, novel antifungal substances produced by the 
fungus Aspergillus niger NH-401. Biosci. Biotech. Biochem. 57: 1222 1224, 1993

20) Ohtani, I.; T. Kusumi, Y. Kashman \& H. Kakisawa: High-field FT NMR application of Mosher's method. Absolute configurations of marine terpenoids. J. Am.
Chem. Soc. 113: 4092 4096, 1991

21) Duh, C.-Y.; J. M. Pezzuto, A. D. Kinghorn, S. L. LEUNG \& N. R. FARNSwORTH: Plant anticancer agents XLIV. Cytotoxic constituents from Stizophyllum riparium. J. Nat. Prod. 50: 63 74, 1987 